\title{
THE STATUS OF REFUGEE RIGHTS IN LIGHT OF MEMORANDUM OF UNDERSTANDING AND MECHANISM OF IMPLEMENTATION Sarah Mahmoud Al-Arasi ${ }^{*}$, Khalid Rbye Ayd Alhuayan ${ }^{2}$ \\ ${ }^{1 *, 2} \mathrm{Al}$-Zaytoonah University of Jordan, Amman, Jordan. \\ Email: ${ }^{1 *}$ dr.arasi@yahoo.com, ${ }^{2}$ hoyankhaledrabee79@gmail.com
}

Article History: Received on $16^{\text {th }}$ May 2020, Revised on $8^{\text {th }}$ August 2020, Published on $17^{\text {th }}$ September 2020

\begin{abstract}
Purpose: According to the importance of the refugee issue and refugee rights and since that Hashimte Kingdom of Jordan did not join the 1951 convention of refugees status and its 1967 protocol and managed to sign the memorandum of understanding instead with UNHCR, this study aimed to tackle the issue of refugees rights and duties between reality and implementation in Jordan.
\end{abstract}

Methodology: This study adopted the descriptive, analytical, and comparative methodology of international and regional conventions, in addition to the comparison between the Jordanian legislation and the Memorandum of Understanding on Refugees with the provisions of international law. Also, it utilized the empirical method by conducting a field study.

Main Findings: Results gained from the questionnaire concluded the refugees on Jordanian territory got rights more than what was stipulated on in the memorandum of understanding signed between the Jordan government and the United Nations high commissioner for refugees' affairs (UNHCR). It also found out that the majority of refugees committed to their responsibilities in maintaining general security and order.

Implications/Applications: This study has addressed the implications of the memorandum of understanding signed between the Jordan government and the United Nations high commissioner for refugees' affairs (UNHCR) by its analysis and application on a random sample of 150 refugees in Jordan, including Syrians in the biggest refugee camp in Jordan; Al- Zaatari refugee camp, in addition to the implications of the memorandum on Iraqi and Yemeni refugees in Jordan.

Novelty/Originality of this study: This study was based on the memorandum of understanding between Jordan and (UNHCR) that was signed in the background of the refugee crisis that our countries witnessed. However, this study was the first to analyze the articles of the memorandum of understanding mentioned above and was backed up with a field study on a random sample of 150 Syrian refugees in Jordan refugees' camps.

Keywords: Refugees, Memorandum, Implementation, Awareness, Mechanism.

\section{INTRODUCTION}

Since the inception of the 20th century, the refuge issue has become a human international concern (Raudel \& MorrisonMétois, 2017). It is a phenomenon that reflects a certain defect in societies which forces their individuals to take refuge in other places because they are unable to secure basic rights for them or any social or political groups (Hagelund, 2020$).$ Besides, they deny individuals participation and freedom of speech, work, development, and belief (Furtak, 2015).

Constant disputes in this world led to a great increase in the number of refugees and that was a burden on the host countries which were overloaded with obligations beyond their capabilities (Alrababa'h, et al., 2020). Therefore, the international community had to help such countries to mitigate their burden. The help could be passed through the legal center of refugees which will clarify their duties and obligations and the duties and obligation of the host countries.

The United Nations attempted to solve the refugee problem through several international agreements, (Byrne \& Gammeltoft-Hansen, 2019) by which it laid down the legal foundations for the method to deal with the issue as this phenomenon aggravated after World War II (Stone, 2018). It was impossible to have a satisfactory solution for it without international cooperation which reduces burdens affecting certain countries during Wars (Hansen, 2018).

Thus, the outcome was the $1951 \mathrm{UN}$ agreement which was designed for refugees protection (Benhabib, 2020; $\underline{\text { Ghosn et }}$ al., 2019). In that agreement, the UN numerated refugee's rights, responsibilities, and obligations toward contracting countries, (Blay \& Tsamenyi, 1990) besides the additional protocol which was signed in 1967 that widened the domains of time and space of that agreement which was signed by 145 states (The 1951 Refugee Convention).

There are numerous countries, such as Jordan, (Akram, 2018) which didn't sign that agreement, (Alfadhli \& Drury, 2018) but instead, signed a memorandum of understanding with UNHCR to put down a mechanism to deal with refugee affairs and individuals (Tsourapas, 2019).

The question that is posed here to which the researchers wanted to find an answer, is: how come that countries which didn't sign the agreement, like Jordan, give refugees rights and commit themselves to certain obligations whenever they face waves of refugees seeking for a safe and secure haven for themselves and their families?

The Hashemite Kingdom of Jordan has been suffering from the refuge problem as it received many refugees of different nationalities (Alshoubaki \& Harris, 2018). It is the favored destination for refuge seekers due to the geographical 
location Jordan enjoys. It is one of the safest countries in the area that suffer from ceaseless conflicts. The kingdom is also one of the countries that provide incessant humane support for refugees worldwide.

The kingdom showed great interest in this group by offering help and services in coordination with international organizations functioning on Jordanian soil. It also helps the group of the refugees from the minute they arrive borders till refugee requests are solved out (UNHCR) and a final decision is taken by which the requests are either accepted or denied.

\section{The problem of the Study}

The problem revolves around the refugee's rights, a mechanism used in presenting them, and obligations of refugees toward Jordan which neither signed the UN protocol nor the agreement relevant to the refugee issue. Besides, it investigates whether the memorandum of understanding signed by the kingdom meets the basic needs of refugees.

\section{Significance of the Study}

The significance lies in the mechanism adopted by Jordan in dealing with the refugee issue regarding their rights and whether such a mechanism complies with international agreements, as the country didn't sign the (UNHCR) agreement and had no legislature concerned with refugees.

\section{Questions of the Study}

The study raises the following four questions:

1. Is there a difference between refugee rights and obligations and the mechanism of implementation in Jordan?

2. Did the memorandum of understanding signed by Jordan and (UNHCR) include all rights stipulated on in international law?

3. What is the legal framework used in Jordan to provide refugees with their rights?

4. What is the significance and legality of the memorandum of understanding signed between Jordan and (UNHCR)?

Many researchers conducted researches on the issue of refugees and their legal status (Kvittingen, et al., 2019) with special reference to securing legal protection for them, in additions to the basic rights stipulated on in international agreements pertaining human rights and other rights stipulated on in 1951 agreement and 1967 protocols.

The researchers outline relevant studies on the issue in the following:

In his study entitled "State responsibility toward refugee seekers", (Halaseh, 2015) discussed the issue of international protection for refugee seekers. He also tackled state obligation toward him and the procedures determining the legal status of that seeker. It also discussed the international mechanism of protection regionally and internationally.

As for the study "our responsibilities to refugees" (Miller, 2019) that had a certain point of view of the protection of refugees by knowing the individuals and countries responsibility towards them, and as the study of (Schiff, 2018) titled "Welcoming Refugees: Mindful Citizenship and the Political Responsibility of Hospitality" discussed the integral role of citizens, legal residents, and the states of protecting and welcoming refugees. Also, Owen (2016) in the study of "Refugees, Fairness and Taking up the Slack: On Justice and the International Refugee Regime" focused on the responsibilities distribution between the host countries to provide human security and refugees protection.

In his study, (Al-Zubaidi, 2016) "To what extent can the state secure legal protection for refugees?" he also tackled in three chapters the extent by which the state obliges itself to legally protect refugees. In chapter one, he tackled relevant legal regulations for refugees protection. In the second, he discussed the presence of Palestinian and Syrian refugees in Jordan.

Finally, in chapter three, he discussed Jordan's ability, being part of the international community, to solve the refugee problem.

As for the study of Bdewi (2016) entitled" The role of international state organizations in protecting refugees: UNHCR as a model". He discussed the concept of refugee right in international law, the status of international protection for refugees, and the stages of its development. Also, he discussed the significance of the role played by state international organizations, specifically, UNHCR in securing protection for refugees and the challenges it encounters.

This study is different from the previous ones because it investigates the actual rights and duties of refugees under the mandate of UNHCR and the mechanism of protecting them in Jordan.

\section{METHODOLOGY}

This study adopted the descriptive, analytical, and comparative methodology of international and regional conventions, in addition to the comparison between the Jordanian legislation and the Memorandum of Understanding on Refugees with the provisions of international law. Also, it utilized the empirical method by conducting a field study. 
This study is based on the provisions of refugees' 1951 United Nations agreement and the appended protocol of 1967, which is the cornerstone in dealing with refugees and securing their needs, in addition to the understanding memorandum signed between the Hashemite Kingdom of Jordan and UNHCR in 1998 and other relevant international agreements.

\section{RESULTS AND DISCUSSION}

The Government of the Hashemite Kingdom of Jordan has proved its ability to overcome the refugee crises - to which it has been subjected despite its limited resources, and to this point, Jordan offers lessons and lessons in the field of refugee relief and compensation. It has also pursued an open-door policy regarding the free education of refugee children and has made great efforts to improve educational opportunities in various ways to ensure that several children are enrolled in education and ensure quality education. On the other hand, some of the basic rights have not been adequately provided to a refugee because of the challenges faced by the Jordanian government, one of the most important of which is the lack of financial support, the large numbers of refugees, and their impact on all the facilities in Jordan, besides, there is a lack of Jordanian legislation in terms of providing for refugee issues, especially those that deal with basic rights such as those of the Ministry of Interior.

The researchers are going to discuss the problem of the study through the following:

\section{What is the nature of the memorandum of understanding signed by Jordan and (UNHCR)?}

Jordan is one of the countries which didn't sign the 1951 Geneva Convention that arranged the relationship between refugees and host countries. Therefore, its internal legislatures lack regulations of rights and obligations related to refugees, though Jordan is a signatory on international agreements on human rights agreements such as the 1984 antipersecution agreement that prevents the extradition of any foreigner to any country where he might be persecuted.

In the absence of such legislation in Jordan, (UNHCR) does the job of receiving refugee applications and take decisions following the memorandum of understanding (Kinchin, 2016). 1981 agreement determines who the refugee is and authorizes the commissioner to perform its duties in protecting refugees and in finding final solutions.

To point out the significance of the memorandum of understanding and refugee rights stipulated upon, the study will be divided into two requisites:

\section{First: Significance and legal stature of the memorandum}

In October 1991, Jordan allowed (UNHCR) to have an office in Amman to play its role in providing international safety for a big number of refugees who got into the country as a result of the Gulf war (M.Marefa.org.,2003). The office then examined refugee applications to determine who deserves to be considered refugees to ensure international safety and to endeavor to find a permanent solution for their problem based on an article (1) of the basic system of (UNHRC) (Halaseh,2006:232).

In April 1998, the Kingdom signed with (UNHRC) an understanding memorandum which was considered the first legal source to protect refugees seeker on Jordanian soil (Davis et al., 2017). The memorandum seconds the minimal international standards of rights protection (Asfahani, 2017).

This memorandum was regarded as one of the basic UN documents for interpreting the mechanism according to which refugee issues were dealt with.

\section{Second: Legal value of the memorandum}

Some researchers consider the memorandum to be just a corollary institution of the general assembly according to the article (22) of the United Nations League. It enjoys privileges and immunities given to UN bodies (Saeeda, 2015).

Concerning the researchers' opinion, they consider the memorandum to be not more than a mere document that specifies the working mechanism with the government of Jordan (Al-Zubaidi, 2016). Regardless of the controversy, the Jordanian legislator doesn't consider the memorandum an independent entity, as it is affiliated with the UN League and its decisions are imposed by the League. More than that, according to legislation in Jordan and following article (23/2) of the Jordanian constitution, no agreement or treaty that incurs expenses on for state treasury or affect the rights of Jordanians is unimplementable, unless it is approved of by the Parliament, pending also that the implicit conditions don't contradict with the explicit ones (Jordanian Constitution,1952, article33/2).

Even though the memorandum didn't stipulate on the majority of refugee rights, if compared to the 1951 agreement, yet it attracted great attention for being the cornerstone in dealing with refugee issues together with the national laws relevant to such issues.

\section{Second: Refugee Rights as Stipulated on in the Memorandum}

The memorandum signed with Jordan in 1998 included some obligations of the Jordanian government toward UNHCR.

The points included in the memorandum of 1998 together with the amendments were: 
Definition of refugees; the memorandum adopted the definition as presented in the 1951 agreement: the refugee is the person who is afraid to return to his own country for the fear of persecution because of race, religion, nationality, or political ideology and doesn't like to go back to his homeland.

\section{Non-refoulement}

Article (2), paragraph (A) of the memorandum indicated that non- refoulement should be respected and the refugees, whose life or freedom would be endangered because of race, religion, nationality, or belonging to a certain group, should not be dismissed (1998 memorandum).

Such a statement is identical to the article (31) of the 1951 treaty on refugees. It constitutes a basic principle in refugee law and a source of international protection. Modern jurisdiction considers it one of the traditional rules in general international law which the state had to honor even though it wasn't a part of the 1951 agreement (Burhan, 1982).

\section{Illegal Entry}

The memorandum tackled the issue of foreigners who entered the Kingdom illegally and were retained. The government left it for the UNHCR office to decide within seven days to reject or accept their applications, (Ward, 2014) excluding those cases whose procedures might need longer, pending it doesn't exceed one month (Article 3 of the memorandum). It is noted that the 1951 agreement on refugees article (31) imposes penalties for illegal entry to the territory of the contracting country.

\section{Religious Practice}

The refugee should be able to practice his religious rituals. Article (6) of the memorandum stated that refugees, as far as possible, should be treated as citizens concerning religious and education rituals for their children. They should not be discriminated against for race, religion, or country (Eghdamian, 2017).

The rituals should not contradict with rules of the Jordanian constitution or general behavior regulations (1998 memorandum).

\section{Right to Litigate}

Article (1) of the memorandum pointed out that the refugee has the right to litigate and to get legal assistance whenever possible, like the native citizen without any discrimination. Such an issue was confirmed by the 1951 refugee agreement (1998 memorandum).

\section{Right to Work}

Article (8) of the memorandum stipulated that to secure a decent life for his family, the refugee with legal residence in the Kingdom can have his own business following functioning laws and bylaws (Meral, 2020). Thus, the refugee's right (Claudena Skran, Evan Easton-Calabria, 2020) to work is conditioned by conformity to national legislation (1998 memorandum).

\section{Right to Practice Professions}

The memorandum also disclosed that the refugee qualified with a certificate accredited by competent Jordanian authorities is allowed to practice a free profession, (Lenner, 2020) pending that he conforms to laws and regulations (1998 memorandum, article 9).

\section{Exemption from Overstay Fines and Departure Tax}

According to the article (10) of the memorandum, the two parties, to find a permanent solution for refugee problems and to facilitate voluntary return or resettlement, they agreed to exempt refugees from overstay fines and departure tax.

\section{Providing Housing, Food and Health Care}

To secure international protection and a decent life for the needy refugees, UNHCR committed itself to help them financially in compliance with the memorandum and that includes housing, food, (Oliver \& Ilcan, 2018), and medical treatment according to the principles adopted by the commissioner (1998 memorandum, article 11).

From the preceding text, one notices that UNHCR maintains responsibility for securing living costs: housing, food, and medication, whereas the 1951 agreement stipulated that housing is the responsibility of the hosting country, pending that the refugee was officially registered as indicated in the article (23) which excluded food costs.

\section{Establishing a joint Mechanism for Emergency and Cooperation}

Article (24) of the memorandum stipulated that in case of emergency when waves of refugees rush into the country, the two parties (UNHCR and Jordanian government) create a joint mechanism for an emergency to secure food, drainage, shelter, and health care, in addition to corporal safety for asylum seekers. 
Such a stipulation is confined to the cases in which Jordan faces large waves of refugees, but was never mentioned in the 1951 agreement (1998 memorandum, article 12).

The memorandum in its provisions focused more on the refugee rights than obligations because he is the weakest in the formula of refugee being not nationally secured. Therefore, the reference to refugee obligations was only mentioned in the article (4) which imposed certain duties on acknowledged refuge seekers concerning Jordan in abiding by rules and regulations linked to general order and any activity that disturbs security or causes embarrassment in the relationship between Jordan and other countries. Whenever there is any infringement, the commissioner office secures entry to a third country (1998 agreement, article 4).

The 1998 memorandum disregarded the following rights accredited for refugees in the 1951 agreement:

\section{Ownership of Movable and Immovable Properties}

The 1951 agreement didn't include such rights which were approved by Jordan according to an article (3) that allowed non-Jordanians to rent and sell immovable properties to non-Jordanians for the sake of residence within the boundaries of the city, pending approval of competent authorities.

\section{Personal Status}

Rights related to marriage, (Elmolla, 2019) birth and death registries stipulated on in the 1951 agreement were absent from the memorandum. According to Jordanian laws, refugees are subject to the personal status law (Verhellen, 2018) which necessitates to officially document marriage contracts besides death and birth cases (groom.ne/archives/68273/retrieved 3/4/2019). Jordan was singled out for a human procedure by which it established sharia courts inside refugee camps to regulate general life and control general behaviors needed for inhabitants to secure life flow in an integrated way (Chandler et al., 2020) to meet life necessities safely and peacefully (www.addustour.com/articles 47613), retrieved (11/4/2019).

\section{Technical and Industrial Ownership}

Article (14) of the 1951 agreement put down rules, missing from memorandum of understanding, to protect inventions and other forms of intellectual property.

\section{The Right to Belong to Associations}

Article (15) of 1951 agreement gave the right for refugees to belong to non-political associations, while such a right wasn't mentioned in the memorandum of understanding.

2008 law of associations and its amendments put down conditions stipulated on an article (8) that the founder of any association must be of Jordanian nationality. Article (11) of the same law necessitated taking the cabinet's approval whenever one of the founders is non-Jordanian.

\section{The Right to Learn}

Article (22) of the 1951 agreement stipulated that refugees have the right to study in schools, (Buckner, Spencer, \& Cha, 2018) but the memorandum didn't refer to such rights.

\section{Freedom of Movement within the Country}

Article (26) of 1951 stipulated that the refugees should be free to move within the country, (Costello, 2018) while the memorandum didn't contain a counterpart article. It is noteworthy that the movement of refugees in Jordan is not restricted; they spread throughout the country.

\section{Identity Card}

Article (27) of the 1951 agreement stipulated that pursuing refugees who do not have identity cards should get them. Such an article is missing from the memorandum of understanding. Jordan has already issued eye print cards for all refugees on its territory to facilitate their transactions. The same law necessitated taking the cabinet's approval whenever one of the founders is non-Jordanian. The card contains domicile, means of entry, and place of issuance (maqar.com 2014, retrieved 3/9/2019).

\section{Travel Documents}

Article (28) of the 1951 agreement stipulated that hosting countries should issue travel documents for refugees, but that was not referred to in the memorandum.

In an attempt to support the refugee process and to mitigate the number of suffering refugees are exposed to and because of the increasing number of refugees, the government of Jordan on 3/3/2014 renewed signature on the memorandum with UNHCR after introducing some amendments to specify the mechanism of treatment with the refugees sponsored by the commissioner (UNHCR, 2015). So articles (3) and (5) of the 1998 agreement was amended as manifested in 2014 
copy according to which the period of refugee seeking was extended to (21) days instead of (7), and in exceptional cases becomes (90) days instead of one month (Modified memorandum of understanding 1998, article 3).

A new item was added to article (5) which allowed the commissioner to issue registry certificates valid for (12) months to those of interest for the commissioner and renewable by the two parties' consent (article (5) of the 1998 memorandum modified n 2014).

Despite the positive developments of the memorandum, yet it doesn't reach the level of the legislature and can be canceled at any time.

\section{Application of Mechanism}

Though Jordan hosts huge numbers of refugees, yet they are given general services like health care, education, and building camps to accommodate them on its soil (Inder, 2018).

Undoubtedly, the application mechanism faces a lot of challenges that hamper providing the refugee his complete rights.

To elaborate on the mechanism used by official establishments and international organizations of concern, the researchers divided this issue into two sections: the role of Jordanian official agencies, in granting the refugee rights and the reality of the refugee obtaining such rights.

\section{The Role of Official Agencies in Granting the Refugee His Rights}

Jordan has taken several procedures and issued many decisions to allow refugees to enjoy sustainable rights (Wake \& Barbelet, 2020) it authorized official bodies to deal with such rights, (Kerll, 1990) each following its responsibilities. The agencies are the ministry of education, ministry of labor, ministry of health, and competent security bodies. Thus, the government enacted contain regulations to control and facilitate the life of refugees regarding entry and residency, as it did with Iraqi refugees in relieving them from penalties once they voluntarily go back home. Also, refugees were granted other several rights such as the right to learn by joining morning public schools or evening sessions once they got a valid annual residence,

The researchers provide examples of how Jordanian government agencies empirically granted refugees such rights as seen in the following:

1. Refugee's entry and residence

Provisions of the law of residence and foreigners, affairs no. (24), 1973 applies to all foreigners when they lawfully enter the country, regardless of their nationalities. That was seen in removing some restrictions that Iraqi refugees used to face at Jordanian borders.

2. The right to learn

The Jordanian Government gave the education sector special attention to absorb refugees in public and private schools.

\section{The Reality of Refugee Rights}

The following tables summarize the frequencies and percentages of refugees regarding age groups, entries to Jordan, refugees rights including free education, health care, right to work, exemption of work permit fees, litigation right, housing, movement through the country, voluntary return, and religious ritual practices respectively.

- These tables are based on a field study by the second author Al-Hoyan, Khaled, on a random sample of 150 refugees in the Al-Zaatari refugee camp in Jordan, in the time between 21/8/2019- 21/9/2019

Table 1: Frequencies and Percentages of Quality Structure in Light of the Memorandum and Mechanism of Application

\begin{tabular}{cccc}
\hline \multicolumn{2}{c}{ Gender } & Frequency & Percentage \\
\hline 1 & Male & 81 & 54 \\
\hline 2 & Female & 69 & 46 \\
\hline & Total & 150 & 100 \\
\hline & Age & Frequency & Percentage \\
\hline 1 & $15-30$ & 60 & 40 \\
\hline 2 & $31-45$ & 70 & 46.6 \\
\hline 3 & $46-60$ & 20 & 13.4 \\
\hline & Total & 150 & 100 \\
\hline & Age & Frequency & Percentage \\
\hline 1 & $15-30$ & 60 & 40 \\
\hline 2 & $31-45$ & 70 & 46.6 \\
\hline 3 & $46-60$ & 20 & 13.4 \\
\hline
\end{tabular}




\begin{tabular}{lll}
\hline Total & 150 & 100 \\
\hline
\end{tabular}

Source: Analysis by author

The study sample of the study revealed that most of the refugees are equal in a number concerning gender- males and females. Their ages are relatively young 15- 46 years old. People of Syrian nationality are the highest in number in Jordan, followed by Iraqi and Yemeni nationalities respectively.

Table 2: Frequencies and Percentages of Entries into Jordanian Territory and why Opted for a Refugee Place

\begin{tabular}{clll}
\hline Entry into Jordanian territory & Frequency & Percentage \% \\
\hline 1 & Through borders & 97 & 64.6 \\
\hline 2 & Land boundaries & 49 & 32.6 \\
\hline 3 & Via airport & 4 & 2.8 \\
\hline & Total & 150 & 100 \\
\hline & Reasons behind choosing Jordan for refuge & Frequency & Percentage \% \\
\hline 1 & Safety & 140 & 93.3 \\
\hline 2 & Vicinity & 10 & 6.7 \\
\hline & Total & 150 & 100 \\
\hline & Cause of exodus & Frequency & Percentage\% \\
\hline 1 & War & 115 & 76.6 \\
\hline 2 & Fear & 35 & 23.4 \\
\hline & Total & 150 & 100 \\
\hline
\end{tabular}

Source: Analysis by author

The study sample unveiled that the reason behind refuge was war and fear. Jordan was chosen for refuge because it is safe and because of the vicinity. Most refugees infiltrated through the fence, through border centers, and very few the airport.

Table 3: Frequencies and Percentages of the Variable of Refugee Identifying His Rights

\begin{tabular}{llll}
\hline \multicolumn{2}{l}{ Rights identifying } & Frequency & Percentage \% \\
\hline 1 & International organizations & 65 & 43.3 \\
\hline 2 & Media & 50 & 33.4 \\
\hline 3 & Official bodies & 35 & 23.3 \\
\hline & Total & 150 & 100 \\
\hline
\end{tabular}

Source: Analysis by author

The sample also revealed that the majority of refugees could identify their rights through international organizations, media, and official bodies.

Table 4: Frequencies and Percentages of Obtaining Free Right to Learn

\begin{tabular}{|c|c|c|c|}
\hline \multicolumn{2}{|r|}{ Were you given the right to learn? } & \multirow{2}{*}{$\begin{array}{ll} & \text { Frequency } \\
101 & \end{array}$} & \multirow{2}{*}{ Percentage \% } \\
\hline 1 & Yes & & \\
\hline \multirow[t]{3}{*}{2} & No & 49 & 32.7 \\
\hline & Total & 150 & 100 \\
\hline & $\begin{array}{l}\text { Were you given free schooling as a } \\
\text { refugee? }\end{array}$ & Frequency & Percentage $\%$ \\
\hline 1 & Yes & 119 & 79.25 \\
\hline \multirow[t]{3}{*}{2} & No & 31 & 20.75 \\
\hline & Total & 150 & 100 \\
\hline & Were there enough schools for learning? & Frequency & Percentage \% \\
\hline 1 & Yes & 121 & 80.6 \\
\hline \multirow[t]{2}{*}{2} & No & 29 & 19,4 \\
\hline & Total & 150 & 100 \\
\hline \multicolumn{4}{|c|}{ The right to learn } \\
\hline & Yes & $\begin{array}{l}\text { Yes } \\
\text { Percentage \% }\end{array}$ & $\begin{array}{l}\text { No } \\
\text { Percentage } \%\end{array}$ \\
\hline & 108 & 71.95 & 28.075 \\
\hline
\end{tabular}

Source: Analysis by author 
Table 5: Frequency and Percentages of Health Care and Free Education

\begin{tabular}{|c|c|c|c|}
\hline & $\begin{array}{l}\text { Did you obtain your right to health } \\
\text { care? }\end{array}$ & Frequency & Percentage \% \\
\hline 1 & Yes & 91 & 60.6 \\
\hline \multirow[t]{3}{*}{2} & No & 59 & 39.4 \\
\hline & Total & 150 & 100 \\
\hline & $\begin{array}{l}\text { Were you treated and given free } \\
\text { medicine, being a refugee? }\end{array}$ & Frequency & Percentage \% \\
\hline 1 & Yes & 89 & 59.25 \\
\hline \multirow[t]{3}{*}{2} & No & 61 & 40.75 \\
\hline & Total & 150 & 100 \\
\hline & $\begin{array}{l}\text { Is there a health care canter close to } \\
\text { your residence? }\end{array}$ & Frequency & Percentage \% \\
\hline 1 & Yes & 102 & 67.95 \\
\hline \multirow[t]{2}{*}{2} & No & 48 & 32.05 \\
\hline & Total & 105 & 100 \\
\hline \multicolumn{4}{|c|}{ Whole arithmetic mean/ Health care right } \\
\hline Question & Yes & percentage & No Percentage \% \\
\hline $\begin{array}{l}\text { Whole } \\
\text { arithmetic } \\
\text { mean }\end{array}$ & 94 & & $37.4 \%$ \\
\hline
\end{tabular}

Source: Analysis by author

The sample unveiled that many refugees were granted health care right and free medicine was given, besides, places for medical treatment are found wherever refugees are (inside or outside campus).

Table 6: Frequency and Work Right Percentages

\begin{tabular}{llll}
\hline & Were you given the right to work? & Frequency & Percentage \% \\
\hline 1 & Yes & 113 & 75.25 \\
\hline 2 & No & 37 & 24.75 \\
\hline & Total & 150 & 100 \\
\hline
\end{tabular}

Source: Analysis by author

The study revealed that many refugees were given the right to work and exempted from work permit fees, due to low wages.

Table 7: Frequency and percentages of living costs and work permit exemption

\begin{tabular}{llll}
\hline & Does the wage you receive meet living costs for you and the family? & Frequency & Percentage \% \\
\hline 1 & Yes & 52 & $34.65 \%$ \\
\hline 2 & No & 98 & 65.35 \\
\hline & Total & 150 & 100 \\
\hline & Were you exempted from work permit fees? & Frequency & Percentage \% \\
\hline 1 & Yes & 119 & 79.25 \\
\hline 2 & No & 31 & 20.75 \\
\hline & Total & 150 & 100 \\
\hline
\end{tabular}

Source: Analysis by author

Table 8: Whole arithmetic mean of right to work

\begin{tabular}{lccll}
\hline Question & Yes & No & $\begin{array}{l}\text { Yes } \\
\text { Percentage \% }\end{array}$ & $\begin{array}{l}\text { No } \\
\text { Percentage \% }\end{array}$ \\
\hline Whole arithmetic mean for the right to work & 94.65 & 55.35 & $63.05 \%$ & $36.95 \%$ \\
\hline
\end{tabular}

Source: Analysis by author

The sample revealed that the majority of refugee wages were enough to meet living costs. The sample also revealed that some got free of- charge work permits. 
Table 9: Frequency and Percentages of Right to Litigate

\begin{tabular}{llll}
\hline & Refugee obtaining litigation right & Frequency & Percentage \% \\
\hline 1 & Yes & 97 & 64.6 \\
\hline 2 & No & 53 & 35.4 \\
\hline & Total & 150 & 100 \\
\hline & Is there a court close to where you live? & Frequency & Percentage\% \\
\hline 1 & Yes & 122 & 81.25 \\
\hline 2 & No & 28 & 18.75 \\
\hline & Total & 150 & 100 \\
\hline
\end{tabular}

Source: Analysis by author

The study revealed that many refugees were given the right to litigate and to file cases to competent courts for investigation.

Table 10: Frequency and Percentages of Providing Housing for Refugees

\begin{tabular}{llll}
\hline \multicolumn{2}{l}{ Were you provided with enough money for housing and food? } & Frequency & Percentage $\%$ \\
\hline 1 & Yes & 77 & 51.25 \\
\hline 2 & No & 73 & 48.75 \\
\hline & Total & 150 & 100 \\
\hline & Were you provided with housing as a refugee? & Frequency & Percentage \% \\
\hline 1 & Yes & 99 & 65.25 \\
\hline 2 & No & 51 & 34.75 \\
\hline & Total & 150 & 100 \\
\hline
\end{tabular}

Source: Analysis by author

The study sample revealed that the majority of refugees were given money to cover the costs of housing and food, though most of them were provided with housing.

Table 11: Frequency and Percentages of Exempting Refugees from Residence and Documentation Fines

\begin{tabular}{llll}
\hline & Were you exempted from overstay fines? & Frequency & Percentage \% \\
\hline 1 & Yes & 42 & 28 \\
\hline 2 & No & 108 & 72 \\
\hline & Total & 150 & 100 \\
\hline & Did you face any problem moving from one place to another in Jordan? & Frequency & Percentage \% \\
\hline 1 & Yes & 53 & 35.3 \\
\hline 2 & No & 97 & 64.7 \\
\hline & Total & 150 & 100 \\
\hline & Did you get identification papers? & Frequency & Percentage \% \\
\hline 1 & Yes & 120 & 79.9 \\
\hline 2 & No & 30 & 20.1 \\
\hline & Total & 150 & 100 \\
\hline & Were the rights provided satisfactory? & Frequency & Percentage \% \\
\hline 1 & Yes & 105 & 70 \\
\hline 2 & No & 45 & 30 \\
\hline & Total & 150 & 100 \\
\hline & Did you feel any discrimination in treatment? & Frequency & Percentage \% \\
\hline 1 & Yes & 30 & 20 \\
\hline 2 & No & 120 & 80 \\
\hline & Total & 150 & 100 \\
\hline
\end{tabular}

Source: Analysis by author

The study revealed that there was no difficulty for refugees to move from one place to another. It also revealed that there no fines were collected for residence overstay. Most of the refugees obtained identification papers and there was no discrimination in treatment.

Table 12: Frequency and Percentages of Those Who Were Asked to Go Back Home Voluntarily or to Be Relocated in A Third Country.

\begin{tabular}{llll}
\hline & Were you offered to voluntarily go back home? & Frequency & Percentage \% \\
\hline 1 & Yes & 24 & 16 \\
\hline
\end{tabular}




\begin{tabular}{llll}
\hline 2 & No & 126 & 84 \\
\hline & Total & 150 & 100 \\
\hline & Were you offered relocation in a third country? & Frequency & Percentage \% \\
\hline 1 & Yes & 33 & 22 \\
\hline 2 & No & 117 & 78 \\
\hline & Total & 150 & 100 \\
\hline
\end{tabular}

Source: Analysis by author

The study sample revealed that refugees were not voluntarily asked to go back home and were never offered relocation in a third country.

Table 13: Frequency and Percentages of Practising Religion Rituals

\begin{tabular}{llll}
\hline & Religious ritual practice & Frequency & Percentage \% \\
\hline 1 & Yes & 150 & 100 \\
\hline 2 & No & 0 & 0 \\
\hline & Total & 150 & 100 \\
\hline
\end{tabular}

Source: Analysis by author

The study also revealed that all refugees freely practiced their religious rituals without any restrictions or discrimination in treatment for any reason.

\section{CONCLUSION}

The study concluded that, though Jordan was not a party in the 1951 agreement regarding refugees, and though it hosted a huge number of them, yet they were granted their rights in compliance with the memorandum of understanding signed with UNHCR, in addition to other rights not stipulated upon in the aforementioned memorandum. The study finally came up that the Jordanian government proved to the whole world that it could pass all crises related to refugees despite its meager resources and followed an open-door policy through which refugee children were able to join schools. However, some basic rights were not satisfactorily provided to refugees due to financial challenges Jordan had to face especially that there was a lack of legislation in-laws of ministries of interior, education, and health-related to refugees.

\section{RECOMMENDATIONS}

After the detailed discussion the researchers presented throughout this study, they would like to recommend to create a ministry for refugee affairs which includes representatives of other ministries of concern and present the memorandum of understanding to the house of representative to proceed with verification procedures, also, to conduct studies that shed light on the positive humanitarian role Jordan played in housing refugees. Also, it is important to increase the level of awareness of employees in all ministries through workshops and seminars on the rights of refugee to be able to deal with them propitiously and establish a database concerned with refugees and asylum seekers to enable concerned bodies to grant them their rights as long as they are on Jordanian territory. Finally, the study recommends enlightening refugees through official instructions and organizations to abide by laws and regulations of the hosting country.

\section{LIMITATION AND STUDY FORWARD}

The study has presented the full analysis of the memorandum of Understanding signed between the Jordan government and the United Nations high commissioner for refugees' affairs (UNHCR) which dealt with refugees rights and status, at the same time it is looking forward and recommending to enact national legislation concerning refugees, and also encourages the joining of the 1951 convention of refugees status by The Hashimite Kingdom of Jordan.

\section{ACKNOWLEDGEMENT}

This study has been written by the help provided by the biggest refugee camp in Jordan, which is Al-Zaatari camp that allowed the authors to preview refugee status in Jordan according to the Memorandum of Understanding, the authors would like to thank the camp's efforts in responding to the researcher's requirements to collect information needed for this study.

\section{AUTHORS CONTRIBUTION}

The first author (Dr. Arasi, Sarah) has taken part of the analysis of the Memorandum of Understanding signed between the Jordan government and the United Nations high commissioner for refugees' affairs (UNHCR), clarifying the refugee rights held within and its implication on refugees, Syrians, Iraqis, and Yeminis in Jordan.

The second author Al-Hoyan, Khaled has provided valuable research of data based on a field study made on 150 random samples of Syrian refugees in the biggest refugee camp located in Jordan. 


\section{REFERENCES}

1. Akram, S. M. (2018). Assessing the Impact of the Global Compacts on Refugees and Migration in the Middle East. International Journal of Refugee Law, 30(4), 691-695. https://doi.org/10.1093/ijrl/eey071

2. Alfadhli, K., \& Drury, J. (2018). A typology of secondary stressors among refugees of conflict in the Middle East: The case of Syrian refugees in Jordan. PLoS currents, 10. https://doi.org/10.1371/curr ents.dis.4bd3e6437bff47b33ddb9f73cb72f3d8

3. Alrababa'h, A., Dillon, A., Williamson, S., Hainmueller, J., Hangartner, D., \& Weinstein, J. (2020). Attitudes toward migrants in a highly impacted economy: Evidence from the Syrian refugee crisis in Jordan. Comparative Political Studies. https://doi.org/10.1177/0010414020919910

4. Alshoubaki, W., \& Harris, M. (2018). The impact of Syrian refugees on Jordan: A framework for analysis. Journal of International Studies, 11(2), 154-179. https://doi.org/10.14254/2071-8330.2018/11-2/11

5. Al-Zubaidi, Ahmad Nedal. (2016). The extent of government obligation to protect refugees. M.A Thesis, Irbid, Jordan: Jordan University.

6. Asfahani, M.G. (2017). Syrian refugees in Jordan. M. A Thesis, Amman, Jordan: Al- Zaytoonah University.

7. Bdewi, B. H. (2016). The role of international governmental organizations in protecting refugees: UNHCR as a model. M.A thesis. Amman, Jordan: University of the Middle East.

8. Benhabib, S. (2020). The end of the 1951 refugee convention? Dilemmas of sovereignty, territoriality, and human rights. Jus Cogens, 2, 75-100. https://doi.org/10.1007/s42439-020-00022-1

9. Blay, S. K., \& Tsamenyi, B. M. (1990). Reservations and declarations under the 1951 convention and the 1967 protocol relating to the status of refugees. International Journal of Refugee Law, 2(4), 527-561. https://doi.org/10.1093/reflaw/2.4.527

10. Buckner, E., Spencer, D., \& Cha, J. (2018). Between policy and practice: The education of Syrian refugees in Lebanon. Journal of Refugee Studies, 31(4), 444-465. https://doi.org/10.1093/jrs/fex027

11. Burhan, A. A. (1982). Right of political asylum: Theoretical study in the asylum theory in International law. Cairo: Dar Al- Nahda Al- Arabia.

12. Byrne, R., \& Gammeltoft-Hansen, T. (2019). International Refugee Law Between Scholarship and Practice. International Journal of Refugee Law, 32(2). https://doi.org/10.1093/ijrl/eeaa011

13. Chandler, H., Boothby, N., McNatt, Z., Berrigan, M., Zebib, L., Freels, P. E., ... \& Majd, E. (2020). Causes of family separation and barriers to reunification: Syrian refugees in Jordan. Journal of Refugee Studies. https://doi.org/10.1093/jrs/feaa033

14. Chica, N., \& Acosta, P. (2018). Psychosocial support to foster social cohesion between refugee and host communities in Jordan. Intervention-Journal of Mental Health and Psychosocial Support in Conflict Affected Areas, 16(2), 147-153. https://doi.org/10.4103/INTV.INTV 40 18

15. Costello, C. (2018). refugees and (other) migrants: will the global compacts ensure safe flight and onward mobility for refugees? International Journal of Refugee Law, 30(4), 643649. https://doi.org/10.1093/ijrl/eey060

16. Davis, R., Benton, G., Todman, W., \& Murphy, E. (2017). Hosting guests, creating citizens: Models of refugee administration in Jordan and Egypt. Refugee Survey Quarterly, 36(2), 1-32. https://doi.org/10.1093/rsq/hdx003

17. Eghdamian, K. (2017). Religious identity and experiences of displacement: an examination into the discursive representations of Syrian refugees and their effects on religious minorities living in Jordan. Journal of Refugee Studies, 30(3), 447-467. https://doi.org/10.1093/jrs/few030

18. Elmolla, J. H. (2019). Birth Registration in Crisis: Exploring a Rights-Based Approach to Birth Registration through the Experience of Syrian Refugees. International Journal of Refugee Law,31(4), 541-566. https://doi.org/10.1093/ijrl/eez043

19. Furtak, T. F. (2015). The refugee crisis-A challenge for Europe and the world. Journal of Civil \& Legal Sciences, 5(1). https://doi.org/10.4172/2169-0170.1000163

20. Ghosn, F., Braithwaite, A., \& Chu, T. S. (2019). Violence, displacement, contact, and attitudes toward hosting refugees. Journal of Peace Research, 56(1), 118-133. https://doi.org/10.1177/0022343318804581

21. Hagelund, A. (2020). After the refugee crisis: public discourse and policy change in Denmark, Norway and Sweden. CMS, 8, 13. https://doi.org/10.1186/s40878-019-0169-8

22. Halaseh, A. S. (2015). State liability toward asylum seeker. Dissertation, Cairo: Cairo University.

23. Halaseh. (2006). The legal position of non-Palestinian refugees in Jordan. Muatah Journal for Research and Studies, 21(2), 232. Muatah University.

24. Hansen, R. (2018). The comprehensive refugee response framework: A commentary. Journal of Refugee Studies, 31(2), 131-151. https://doi.org/10.1093/jrs/fey020

25. https://www.Addustour.com/articles/47613. Retrieved on 5/4/2019.

26. https://www.geiroom.net/archives, 68273. Retrieved on 3/4/2019.

27. https://www.maqar.com. (2014). Retrieved on 3/4/2019

28. https://www.marefa.com.org. Retrieved on 1/4/2019.

29. Inder, C. (2018). The origins of 'burden sharing' in the contemporary refugee protection regime. International Journal of Refugee Law, 29(4), 523-554. https://doi.org/10.1093/ijrl/eex047 
30. Jordanian Constitution (1952). Article 33/2.

31. Kerll, H. W. (1990). New Dimensions of the Global Refugee Problem and the Need for a Comprehensive Human Rights and Development-Oriented Refugee Policy. International Journal of Refugee Law, 2(Special_Issue), 237-251.https://doi.org/10.1093/reflaw/2.Special_Issue.237

32. Kinchin, N. (2016). The implied human rights obligations of UNHCR. International Journal of Refugee Law, 28(2), 251-275. https://doi.org/10.1093/ijrl/eew033

33. Kvittingen, A., Valenta, M., Tabbara, H., Baslan, D., \& Berg, B. (2019). The conditions and migratory aspirations of Syrian and Iraqi refugees in Jordan. Journal of Refugee Studies, 32(1), 106-124. https://doi.org/10.1093/jrs/fey015

34. Lenner, K. (2020). "Biting our tongues": Policy Legacies and Memories in the Making of the Syrian Refugee Response in Jordan. Refugee Survey Quarterly. https://doi.org/10.1093/rsq/hdaa005

35. Memorandum of understanding; (1998). Articles 1, 3,6,7,8.

36. Meral, A. G. (2020). Assessing the Jordan Compact One Year On: An opportunity or a barrier to better achieving refugees' right to work. Journal of Refugee Studies, 33(1), 42-61. https://doi.org/10.1093/jrs/fez074

37. Miller, D. (2019). Our Responsibilities to Refugees. Proceedings of the 2018 ZiF Workshop "Studying Migration Policies at the Interface Between Empirical Research and Normative Analysis.

38. Oliver, M., \& Ilcan, S. (2018). The Politics of Protection: The Right to Food in Protracted Refugee Situations. Refugee Survey Quarterly, 37(4), 440-457. https://doi.org/10.1093/rsq/hdy013

39. Owen, D. (2016). Refugees, fairness and taking up the slack: On justice and the international refugee regime. Moral Philosophy and Politics, 3(2), 141-164. https://doi.org/10.1515/mopp-2016-0001

40. Ruaudel, H. \& S. Morrison-Métois (2017), "Responding to Refugee Crises in Developing Countries: What Can We Learn From Evaluations?" OECD Development Co-operation Working Papers, No. 37, OECD Publishing, Paris, https://doi.org/10.1787/ae4362bd-en

41. Saeeda, H. (2015). Forced migration and refugee system of protection in Jordan: Syrians as a model- M. A Thesis, Palestine: Bir Zeit University.

42. Schiff, J. L. (2018). Welcoming refugees: Mindful citizenship and the political responsibility of hospitality. Signs: Journal of Women in Culture and Society, 43(3), 737-762. https://doi.org/10.1086/695305

43. Skran, C., \& Easton-Calabria, E. (2020). Old concepts making new history: Refugee self-reliance, livelihoods and the 'refugee entrepreneur'. Journal of Refugee Studies, 33(1), 1-21. https://doi.org/10.1093/jrs/fez061

44. Stone, D. (2018). Refugees then and now: memory, history and politics in the long twentieth century: an introduction. Patterns of Prejudice, 52, 2-3, 101-106. https://doi.org/10.1080/0031322X.2018.1433004

45. Tsourapas, G. (2019). The Syrian refugee crisis and foreign policy decision-making in Jordan, Lebanon, and Turkey. Journal of Global Security Studies, 4(4), 464-481. https://doi.org/10.1093/jogss/ogz016

46. UNHCR. (2015). Beyond Detention: A Global Strategy to Support Governments to End the Detention of Asylum-Seekers and Refugees 2014-2019. International Journal of Refugee Law,27(2), 375-389. https://doi.org/10.1093/ijrl/eev025

47. UNHR, The 1951 Refugee Convention. https://www.unhcr.org/1951-refugee-convention.html

48. Verhellen, J. (2018). Cross-Border portability of refugees' personal status. Journal of Refugee Studies, 31(4), 427-443. https://doi.org/10.1093/jrs/fex026

49. Wake, C., \& Barbelet, V. (2020). Towards a refugee livelihoods approach: Findings from Cameroon, Jordan, Malaysia and Turkey. Journal of Refugee Studies, 33(1), 125-142. https://doi.org/10.1093/jrs/fez033

50. Ward, P. (2014). Refugee cities: reflections on the development and impact of UNHCR urban refugee policy in the Middle East. Refugee Survey Quarterly, 33(1), 77-93. https://doi.org/10.1093/rsq/hdt024 